\title{
WHEN NATIONAL STEREOTYPES BECOME A BRAND: THE CASE OF SPAIN'S DESTINATION MARKETING
}

\author{
Miriam Soriano Procas* \\ Departament d'Ensenyament. Generalitat de Catalunya \\ https://orcid.org/0000-0001-9962-8663 \\ Antonio Terrón Barroso** \\ Aston University. Birmingham \\ https://orcid.org/0000-0002-6456-1742
}

\section{ABSTRACT}

This paper aims to explore the role that the Spanish central government seems to have historically played on the conformation of national stereotypes and clichés through the campaigns launched to promote the country as a holiday destination abroad. With this objective in mind, a qualitative analysis on the use of images associating the country and its people (s) with different forms of exoticism has been carried out. Special attention has been paid to representations of the country through soft power factors such as sun, beaches, arts or gastronomy and Spaniards through traditionalism and, more recently, through celebrities.
\end{abstract}

Keywords: nation brand; Spain brand; Spanish national stereotypes; Spanish soft power; celebrity diplomacy.

\section{Cuando los estereotipos nacionales se convierten en marca: el caso del marketing turístico español}

\section{RESUMEN}

Este artículo explora el papel que el Gobierno central de España parece haber tenido en la creación histórica de estereotipos y clichés nacionales a través de las distintas campañas lanzadas para promocionarse internacionalmente como destino turístico. Para ello, se ha

Fecha de recepción: 12 de septiembre de 2019.

Fecha de aceptación: 4 de abril de 2020.

*E-mail: msoria30@xtec.cat.

** School of Languages and Social Sciences, Aston Street, Birmingham, B47ET, UK. E-mail: terr1501@ aston.ac.uk. 
llevado a cabo un análisis cualitativo sobre el uso de imágenes que han asociado al país y sus gentes con diferentes formas de exotismo, destacándose las representaciones mediante factores del poder blando como el sol, el mar, el arte o la gastronomía en el caso de España y, en el caso de los españoles, mediante formas de vida tradicionales o, más recientemente, a través de personalidades destacadas.

Palabras clave: marca-país; marca España; estereotipos nacionales; poder blando, celebrity diplomacy.

\section{INTRODUCTION}

Spain was officially aware of the importance that tourism could have for its economy at

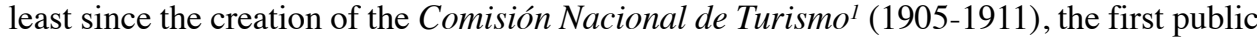
institution in the history of the country conceived to develop touristic activities within its borders. Over the course of history, other national institutions such as the Comisaria Regia del Turismo ${ }^{2}$ (1911-1928), the Patronato Nacional del Turismo ${ }^{3}$ (1928-1936), the Dirección General del Turismo ${ }^{4}$ (1938-1951), the Ministerio de Información y Turismo (1951-1992), Turespaña 5 (1992-present) or the Alto Comisionado del Gobierno para la Marca España ${ }^{6}$ (2012-present) have kept this interest in tourism alive.

According to Noya (2013), Spain started its promotion as a tourist destination abroad in the early twentieth century with the aim of attracting international attention through which new sources of income could be generated. Bearing in mind this early interest of the country in developing touristic activities within its territories, the fact that the Spanish authorities only started to monitor its image abroad a short while ago can be surprising. Indeed, the first organisation specifically created in Spain to deal with the public image of the country abroad-The Alto Comisionado del Gobierno para la Marca España [High Government Commission for the brand Spain] - was established in 2012, more than one century after the Comisaría Regia del Turismo was created. In its articles of association ${ }^{7}$, the Commission for the brand Spain stated that its raison d'être followed the initiatives of other states to control the public performance of their country brands. Nowadays, the definition offered by the official website of marca España [brand Spain] $]^{8}$ claims that the country brand is:

"a long term State policy, aimed at strengthening our country's image, both among Spanish citizens and beyond Spanish borders. A Royal Decree 998/2012, of 28 June,

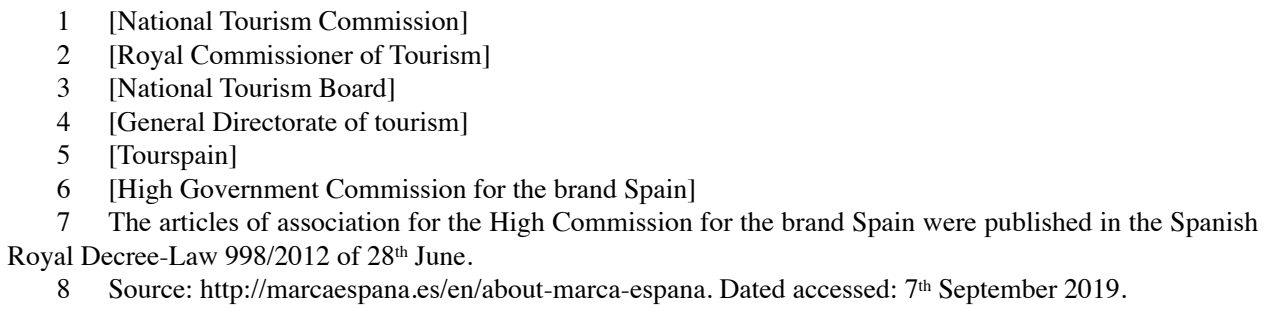

8 Source: http://marcaespana.es/en/about-marca-espana. Dated accessed: $7^{\text {th }}$ September 2019. 
created the position of a High Commissioner of the government for Marca España. Its tasks are planning, encouraging, and coordinating all activities carried out by all public and private agencies seeking to promote a stronger image of Spain".

\section{OBJECTIVES AND METHODOLOGY}

The main aim of this article is to study how the Spanish central government appears to have historically contributed to spreading stereotyped images and clichés about the country and its people (s) through the different marketing campaigns launched to promote its territories as a tourist destination abroad. In order to achieve this goal, we have analysed the presence of stereotypical images and clichés in the audiovisual materials included in the different campaigns launched by the Comisaría Regia del Turismo ${ }^{9}$ (1911-1928), the Patronato Nacional del Turismo ${ }^{10}$ (1928-1936), the Dirección General del Turismo ${ }^{11}$ (19381951), the Ministerio de Información y Turismo (1951-1992), Turespaña12 (1992-present) and the Alto Comisionado del Gobierno para la Marca España ${ }^{13}$. Due to their recurrent presence in the campaigns, the specific sets of images that have particularly caught our attention are those associating Spain with soft power factors such as sun, sea, arts and gastronomy on the one side and Spaniards with rural life and traditionalism on the other. Escalona, Sáez and Sánchez-Valverde (2017) describe soft factors as "elements of the environment, landscape, and culture which favour quality of life; a lively local atmosphere, ethnic and social diversity, a welcoming and tolerant population, and so on". Soft factors contrast with hard factors, which the same authors consider to be "easily monetisable ingredients" such as "infrastructure, income level, purchasing power, productive structure, business typology, and firm diversity". Apart from the association with soft factors, we have also noticed a trend toward including celebrities to represent Spaniards in the last campaigns. This phenomenon is known as celebrity diplomacy (Cooper and Frechette, 2015).

Our qualitative analysis on the campaigns has been carried in three steps. Firstly, we have gathered together the audiovisual materials included in the different campaigns launched since Spain started to promote its territories abroad as a holiday destination from the beginning of the twentieth century up to the present time. We have mainly used as information sources the files currently available on the website of Tourspain and, for some of the campaigns, the academic works published by Fernández Poyatos and Valero Escandell (2015) and Porres Guerrero and Foranda Robles (2019). Secondly, we have critically analysed the presence of images associating the country and its people (s) with the classic Spanish stereotypes and clichés related to their alleged exoticism and traditionalism (Juderías, 1914; Ucelay, 1990; Noya, 2002, 2013; Feo et al., 2004; Lucena, 2006; Balfour and Quiroga, 2007; Mariné-Roig, 2011 and Núñez Florencio, 2015). Finally, we have organised these stereotypical representations found in the different campaigns according to their common narrative themes and the concrete (soft) factors included in them.

\footnotetext{
9 [Royal Commissioner of Tourism]

10 [National Tourism Board]

11 [General Directorate of tourism]

12 [Tourspain]

13 [High Government Commission for the brand Spain]
} 


\section{SPANISH STEREOTYPES AND CLICHÉS: THE ROOTS OF EXOTICISM}

Lippman (1922) claimed that stereotypes are the result of a reductionist process that allows turning something complex into something much simpler. In fact, the construction of stereotypes for Lippman involves a process of overgeneralisation in which assumptions based on unfounded ideas play a key role. As a reactive mechanism, humans tend to stereotype people, places and cultures that they are in contact with but do not recognise as their own. In a certain way, attributes are assigned to these unfamiliar "others" in order to interact with them. The stereotyped representation of these "others" and "their ways" is normally shared by different communities, which makes them easily spreadable through social communication tools. Countries' images and national stereotypes can be considered representations of otherness displayed in media internationally. However, it is worth noting that, in this vein, Storm (2013) suggests that the image of a country is the result of complex interaction processes that occur between images created within and outside its borders.

Núñez Florencio believes that in order to understand how Spain is seen abroad nowadays, we should fully comprehend first what the country has been along its history and how this is conditioning whatever it is nowadays (2015:174). It was indeed during the Middle Ages when the crusades, the Catholic Re-conquest and the Way of Saint James began to generate initial impressions about Spain and its people (s) worldwide (Lucena, 2006:221). Some examples of these first ideas can be found in the references made to Spain and Spaniards in the Codex Calixtinus, a 12th-century illuminated manuscript containing a compilation of information and recommendations for pilgrims following the Way of St. James to the shrine of the apostle, located in the cathedral of Santiago de Compostela. Spaniards from different regions of the north of country were portrayed in this book mainly as sharp-minded, poor, deprived and xenophobic (Feo et al. 2004: 555).

By the end of the Middle Ages, the situation of Spain began to change while its colonies were getting expanded all over the world. In this line, Núñez Florencio (2015) points out that the country began its consolidation as the first imperial power of Modern History by the end of the Late Middle Ages. The expansion of its overseas territories made Spain the world most important colonial empire at the time and the first modern European colonial power (Núñez Florencio 2015:174). This flourishing period took place over the sixteenth and seventeenth centuries. Along these two centuries, Spain held the privileged position of being the world ruling artistic and military power until England started to emerge as the new rising colonial empire in the eighteenth century. After this splendorous period of prosperity, Spain gradually lost its colonies and, consequently, its world power and importance. This progressive decline together with the episodes around the obscure Spanish Inquisition generated the so-called Spanish Black Legend (Juderías, 1914), a term that has been widely used by different scholars to describe the periods of generalised decadence among the Spanish history but, especially, the fall of the Spanish Empire.

According to Noya, an increasing interest towards Spain started to flourish in times when the Grand Tour ${ }^{14}$ was becoming popular (2013: 63). While Spain initially remained

14 The term Grand Tour was coined for the first time by Richard Lassels (1670) in the book El Voyage d'Italie [The travel of Italy] to describe the voyage that British aristocrats pursued to different points of Europe, 
out of the paths followed by travellers - whose main routes went over Italy and France-, Jiménez and Prats argue that some voyagers began to visit the north of Spain lured by the southern exoticism of the country and the protection offered by the control of Napoleon (2006:154). In line with Jiménez and Prats, Núñez Florencio mentions that, even though Spain was off-site the main routes toward Italy and France from the UK or the north of Europe, travellers found in the Iberian Peninsula a sort of mixture between "the European" and the exoticism of "the Hispanic" that rapidly caught international attention (2015:180). In parallel to the rising interest in Spain as a destination for the Grand Tour, the country was undergoing one of the most thriving stages of its national history: the Golden Age.

The Golden Age is defined by the Encyclopædia Britannica as "the period of Spanish literature extending from the early 16 th century to the late 17 th century, generally considered the high point in Spain's literary history ${ }^{15}$ ". Bellman went beyond this definition and included in this period the pictorial works of Velázquez and, lately, the role that the enlightened Spanish monarchy played to promote research and knowledge within the country and abroad. According to Bellman's thoughts, the Spanish Golden Age contrasted with the exoticism of the country which, at the time, had been already widely spread all around Europe (1998:185).

The splendorous cultural periods of the Spanish Golden Age and the Enlightenment come to a definite end in the nineteenth century, which took the country back into a new generalised period of decline. This situation reinforced one more time the reestablishment of the Spanish Black Legend. While most countries in Europe were deeply getting immersed into the emerging industrial revolution and, at the same time, starting to create the roots of the modern nations they are nowadays, Spain stayed aside and moved backwards to the profound Catholic traditionalism that Carlism ${ }^{16}$ promoted all around the country. In this concern, MacClancy points out that Carlists were totally against industrialisation and centralisation but pro rural life: "in place of such evils [industrialization and centralization] they [Carlists] advocated a traditionalist form of Roman Christianity and the maximum degree of local autonomy (...) while remaining within the frame of the Spanish State" (2010:7). This way, whereas other European states were conquering new overseas colonies, Spain was losing its own; whereas Spain's peer countries in Europe were involved in the creation of major state nationalisms, the Spanish peripheral nationalisms of Catalonia and the Basque Country were starting to deepen their roots; and, whereas in most countries of the Old Continent the Marxist socialism began to develop, Spain hosted the strongest anarchist movement in Western Europe (Lawrence, 2010). As was to be expected from such a bustling century as the $19^{\text {th }}$ was for Spain, the visions that the rest of Europe and the world had on the country were inevitably drowned back to its exoticism. Spain consequently became a sort of

mainly to Italy and France, with the aim of complete their education and get to know the pillars of the classic cultures of Rome and Greece, the French and Italian Renaissance and, lately, the Spanish Enlightenment.

15 Date accessed: 02/09/2019. Available at: https://www.britannica.com/art/Golden-Age-Spanish-literature

16 The Encyclopædia Britannica defines Carlism in its online entry dedicated to the term as a "Spanish political movement of traditionalist character, originating in the 1820s in the apostólico or extreme clerical party and mobilized in 1827 in the form of paramilitary Royalist Volunteers. This opposition to liberalism crystallized in the 1830s around the person of Carlos María de Borbón (Don Carlos), younger brother of King Ferdinand VII (...)". Date accessed: September 5, 2016. Available at: https:/www.britannica.com/topic/Carlism 
oriental enclave located not far from some of the most advanced states of the planet led by England. Within this context, Noya states that, by the end of the nineteenth century, Spain began to be a victim of the ethnocentric views which started to emerge in the industrialised areas of Western Europe. According to his thoughts, Spain began then to be represented within European collective imaginaries as a sort of oriental paradise bridging between Europe and Africa and between the civilised Western and the feral Eastern (2013:64).

Also focusing on the oriental and exotic visions that Europeans started to develop again by the end of the nineteenth century about Spain and its people (s), García Cárcel coined the term Yellow Legend (1998:220). This new term intentionally contrasted with that of Black Legend introduced by Juderías in 1914. Unlike the Black Legend, the Yellow Legend did not focus exclusively on the negative connotations around the image of Spain since García Cárcel wanted it to gather together both the positive and negative connotations that the country evoked within foreign collective imaginaries.

Due to the generalised proliferation of war conflicts all around the planet but, especially, in Europe, the twentieth century was another tumultuous period for Spain. According to Ferguson (2007), this century can be considered the bloodiest of all periods in the history of humanity. Although Spain remained officially neutral in the two World Wars ${ }^{17}$, it suffered itself a ferocious civil war and a later dictatorship that ended up being the second largest in Europe after Salazar's in Portugal (Santana-Pereira, Raimundo and Costa Pinto, 2016:5). However, according to Ucelay, the Spanish Civil War was not an obstacle for restraining the formation of images about Spain within foreign collective imaginaries as travellers from all around the world kept on visiting the country during the conflict and Franco's dictatorship (1990:23). In this regard, Núñez Florencio notes that, during this period of time, all the stereotypes previously associated with Spain - such as those around the figure of Don Quixote de La Mancha, bullfighting, passionate people, violence and hope for freedom and individualism - were recurrently used to depict the Spanish territories and its people (s) internationally (2015:182). Once the Spanish Civil War was over and Franco's regime settled down, the old romantic idea of Spain as an exotic oriental paradise within Western Europe was gradually updated and adapted to the new century. These visions were intentionally controlled by the Spanish government led by Franco with the aim of attracting international visitors who could introduce foreign currency into the country (Sánchez, 2001). With this particular objective in mind, the ultra-Catholic moral of Francoism tried to get rid of the sexual connotations that were already associated with the Spanish woman by reinforcing the presence of images linking the country to partying and bullfighting instead (Noya, 2013:71). The efforts bore fruit and Spain started to gradually attract an important part of the mass tourism developing at the time in the industrialised nations of Western and Northern European nations. In this vein, Wright states that the idea of considering tourism a beneficial activity for Spain took root under Primo de Rivera's dictatorship but experienced its climax under Franco's regime, especially after visas for Western European tourists were

17 Morales Lezcano (1940) and Sáez Rodríguez (2010) claim that Spain indirectly took part in the Second World War with minor actions justified by the affinity that Franco showed towards Hitler's regime. 
abolished in 1959. This way, the country was able to earn in 1974 "more in gross terms than any other European country for tourism" (Wright, 1977:146-147). The importance of tourism for the country has been kept crucial ever since ${ }^{18}$.

With regards to the present touristic image of Spain among foreign collective imaginaries, Núñez Florencio has concluded that although some positive changes have occurred, it is still mostly based on the old stereotypes related to the imperial and romantic Spain that Don Quixote travelled (2015:183). According to the results of the study he leaded on the image of the country through opinion polls conducted on foreign visitors in 2015 , Núñez Florencio claims that although the visions on the country are good in leisure, gastronomy, party, entertainment, art and creativity, they turn into negative in terms of efficiency, reliability, trust, daily work, research, science, education, business, industries, technology, etc. (2015:184). We believe these empirical data gathered together by Núñez Florencio support the current legitimacy of the positive-negative dichotomy that García Cárcel (1994) described under what he called the Spanish Yellow Legend. Moreover, they also serve to exemplify the dependence of the country image on its soft power factors.

Núñez Florencio has highlighted as well that the Spanish Transition to democracy ${ }^{19}$, the Movida Madrileña ${ }^{20}$ and some international events such as the Olympic Games of Barcelona in 1992 or the Universal Exposition of Seville in the same year contributed to spread positive perceptions on the country abroad. With these events, images of decline turned into vitality and new positive conceptualisations got blended in with the consolidated romantic visions that already existed about the country and its people (s) (2015:182).

Finally, it is also worth noting that the financial crisis that recently affected the whole Eurozone but, especially, Mediterranean countries including Spain, could be playing an important part in the current image of the country abroad. In this regard, Noya (2013) suggests that a new period of the Black Legend could be taking place. According to his thoughts, within the European Union, Northern countries are carrying out a smear campaign against their southern partners, which is contributing to expand negative perceptions about them worldwide (2013: 263).

\section{THE MARKETING CAMPAIGNS: SPAIN SELLING SPAIN}

Along this section we will pay individual attention to all the different marketing campaigns that have been launched by the Spanish central government to promote the country

18 According to the World Tourism Organisation's report UNWTO Tourism Highlights Edition 2018, Spain was the second country in the world after China in terms of income generated by tourism.

19 The term Transición refers to the Spanish transition from the dictatorship of Franco to the democratic system that rules in the country nowadays.

20 Wharton states that "the movida madrileña of the 1980's is probably one of the most celebrated European cultural movements of the latter part of the twentieth century. As a natural reaction to the end of over forty years of reactionary conservatism under the Francoist regime, the movida madrileña was an event which had been waiting to happen for a long time and its close association with a great period of political, social and economic change in contemporary Spain has only helped to add to its cultural currency and mystique since then. The continuing presence in the Spanish cultural scene of leading movida madrileña figures such as Pedro Almodóvar and Agatha Ruiz de la Prada is a further factor which has helped to cement the idea of this movement or scene as the major cultural movement in 1980's Spain and indeed, the source and direct inspiration for radical sociocultural change in a post-Francoist Spain." (2015: 51). 
as a touristic destination abroad since the beginning of the twentieth century up to the present time. Our starting point coincides with the first efforts that the country made to actively start its promotion as an international holiday destination in 1914. Our analysis concludes with the most recent campaign, "Spain in 10 seconds", which was aired in April 2018.

\subsection{First promotion efforts (1914-1948)}

With the creation of the first public organisation to deal with tourism in Spain - the Comisión Nacional de Turismo ${ }^{21}$-Spain officially got involved in the process of creating and managing its own international image. The main objective of this institution was to attract high purchasing-power tourists who could bring foreign money to the country, at the time an impoverished territory due to the different wars through which its last colonies were $\operatorname{lost}^{22}$. Spain participated then in some international events with the intention of promoting its new policies supporting the development of tourism within its borders (Bayón, 1999:27). Special attention was paid to the United States since, among world's wealthy countries, its inner economy was one of the less affected by World War I (Braun and McGrattan, 1993:207).

With the advent of the twenties, the catastrophic consequences that World War I brought into the economy of Europe progressively started to improve and led the boom of the Roaring Twenties ${ }^{23}$ began. Spain did not want to miss this opportunity and therefore started to put more emphasis on the development of tourism within its frontiers. The country took at the time the first steps towards the professionalisation of the sector (Bayón, 1999:571-573). However, this ideal background for the development of new economic activities along the twenties drastically faded away in the thirties due to the onset of the Spanish Civil War (1936-1939) and World War II (1939-1945). Despite all the difficulties that these bellicose conflicts implied for Spain and the rest of Europe respectively, the Spanish authorities did not stop the promotion of the country abroad. In fact, it was along this period when Spain launched its first official advertising images targeted to international markets. These images were included in a series of posters accompanied by texts written either in English or French (Fernández Poyatos and Valero Escandell, 2015). It is noteworthy that two of these posters included representations of Spanish people and, in both cases, the figure of a woman was shown in the foreground. More precisely, one of them presented a woman accompanied by two men, wearing all traditional aldeano costumes ${ }^{24}$. The text accompanying this image reads "Spain is different". In a second poster depicting people, the central image of a woman with make up on and wearing a tight black dress including

21 The Comisión Nacional de Turismo [National Tourism Commission] was created in 1905 with the aim of dealing with 'la industria de los forasteros' [the industry of foreigners] (González, 2005-17).

22 In 1898, The Treaty of Paris made official that Spain had lost Puerto Rico, Cuba and the Philippines after the short Spanish-American War that took place the same year.

23 Streissguth (2007) defines the period of the Roaring Twenties in the preface of its book The Roaring Twenties as 'the true beginning of the $20^{\text {th }}$ century, a time when cars, automation, and scientific management transformed daily life and work and entertainment in all its forms became big business'.

24 The term "aldeano" can be translated into English as "parochial". According to Hoyos Sáinz \& De Hoyos Sancho (1953), this traditional costume was well-extended on rural areas of Spain and South America in the forties. 
mantilla and peineta ${ }^{25}$ overlies what seems to depict the city of Granada. A text that reads "Sunny Spain" was also included. The other posters did not include any representation of people and focused on particular places such as the coastal resort of Sitges (Barcelona) and what seems to be a monastery. The poster about the coastal resort of Sitges included a text that reads "Plage d'or, Sitges (Barcelona), station d'hiver" [Golden beach, Sitges (Barcelona), Winter station] while the poster with the monastery reads "Espagne, un voyage en Espagne est une date dans la vie" [Spain, a travel to Spain is a date in life]. As can be easily observed, these first advertising images were intended to link the country with sun, beaches and some of its historical sites while the representation of Spaniards was limited to people wearing traditional dresses with women as their focal points.

\section{Figure 1 \\ FIRST POSTERS}

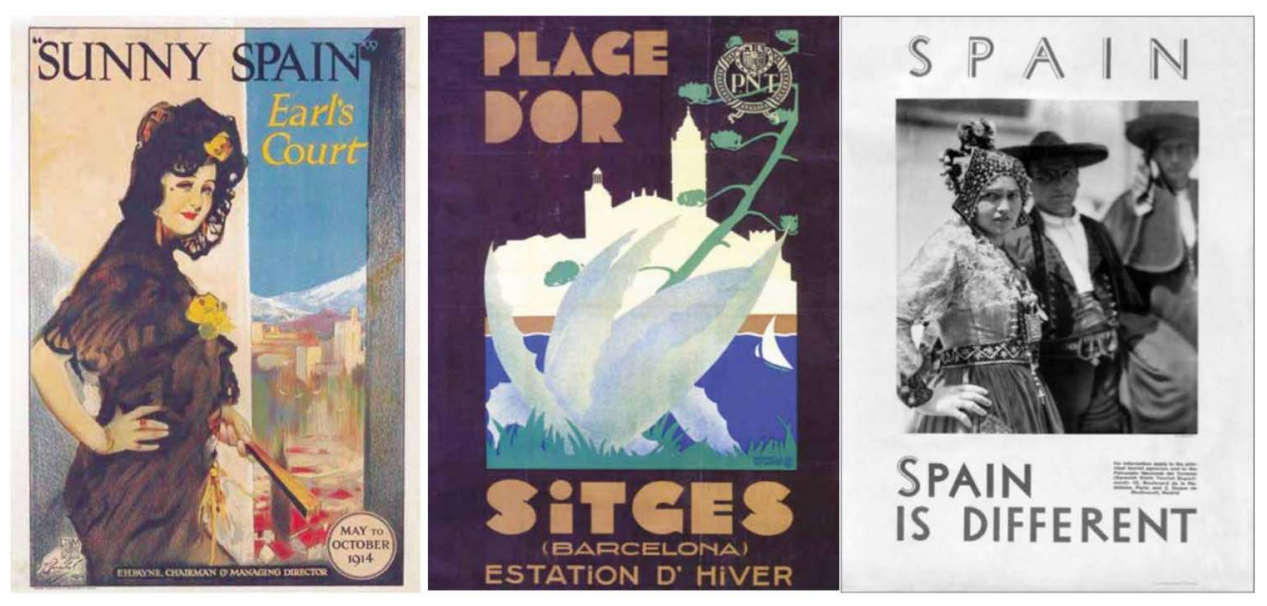

Source: Fernandez Poyatos, M.D. and Valero Escandell, J.R. (2015).

\subsection{Spain is different (1948-1984)}

As shown on the posters of figure 1, from the very first promotional efforts made to promote Spain as a tourist destination abroad, one of the most recurrent ideas used by the Spanish central government was the alleged singularity of its territories and its people (s). To this regard Pack claims that "despite certain indigenous origins, the history of leisure and tourism in Spain became entangled in an often-obsessive struggle to overcome the stigmas of national difference and an alleged incapacity to adapt to modern ways" (2008:1). The famous slogan "Spain is different" seems to openly echo this position. Moreover, it is the slogan that has been used for the longest period of time in the promo-

25 Katherine Zoepf (2006), from the New York Times, described the peineta as a "decurved tortoiseshell comb that holds a Flamenco dancer's upswept hair and lacy black mantilla in place". 
tional history of Spain as a tourist destination abroad, having been in force from the early twentieth century until well into the eighties.

Even though it was used for the first time in a poster launched in 1935 (see figure 1), Fernández Fuster places the birth of "Spain is different" as an official slogan in 1948, when three posters containing it with some minor modifications saw the light. The particular version shown in these three posters reads "Spain is beautiful and different. Visit Spain". The slogan was used again in 1957 but, in this occasion, already in its final form as "Spain isdifferent" (Bayón, 1999: 431-432). It is worth mentioning that the last campaign including the slogan was aired in 1984 and depicted Spaniards wearing flamenco dresses while riding horses in a festive atmosphere which also included bullfighting in a corrida (see figure 2).

Figure 2

\section{SPAIN IS DIFFERENT}
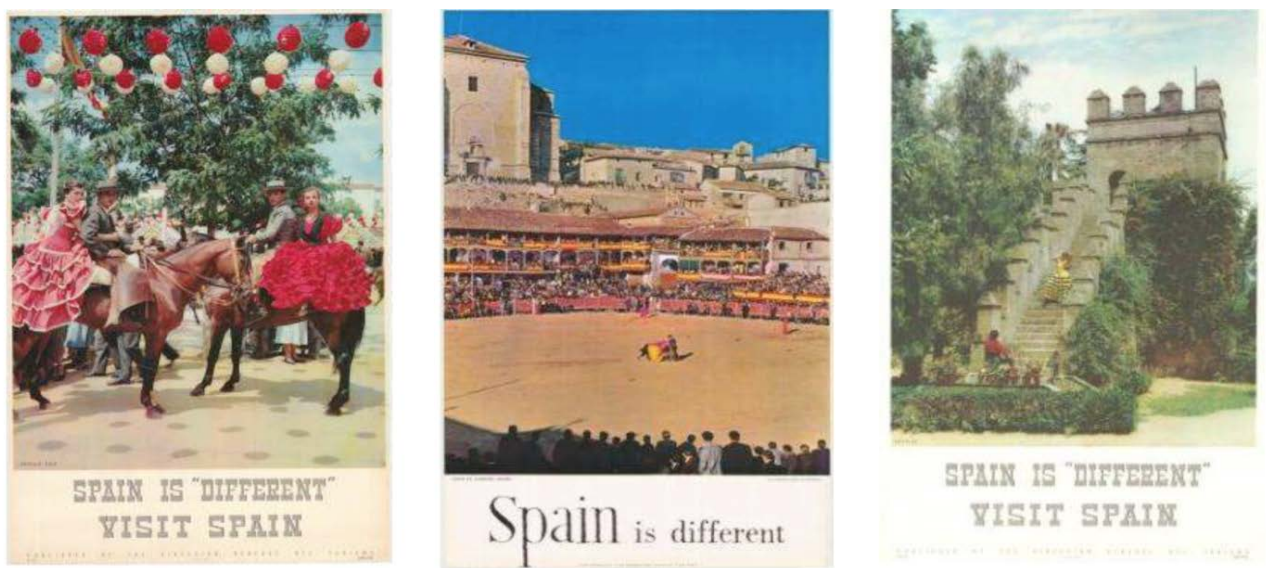

Source: http://ww2.ac-poitiers.fr/espagnol/IMG/pdf/estrategia-mk-turespana.pdf. Last date accessed: 26/03/2020.

It is important to bear in mind that the re-establishment of the democracy in Spain after Franco's dictatorship, which took place along the second half of the seventies, brought in its wake profound changes in the functioning of the country and its power structure. As could be expected, these structural changes affected the promotion of the country and its territories abroad. In this regard, Garrido Lora highlights that the control over communication campaigns to promote the country was transferred from the central government to the different regions right after the new democratic Spanish Constitution was passed in 1978. This made possible that the different Spanish national ideologies and identities started to be reflected on the promotion of the country abroad (2005:128). According to the Spanish Constitution of 1978, still in force nowadays, the Spanish central government will promote the whole country as a unique and uniform destination while the different Spanish regions will require an authorisation from the central government to be able to autonomously promote their territories. This prerogative has generated some disagreements between the central authorities and the government of the different regions of the country, especially Catalonia (Bayón, 1999:437). 


\subsection{Spain. Everything under the sun (1984-1991)}

With a brand-new first logo-the Sun of Miró-adopted in 1984, Spain started to build a new chapter on the history of the country's promotion abroad. In the same year Turespaña [Tourspain, the National Spanish Institute for Tourism] was created within the Spanish Ministry of Industry, Commerce and Tourism. Since then, all the campaigns that have promoted the country as an international tourist destination have been launched and monitored under the supervision of this institution.

\section{Figure 3}

\section{TOURSPAIN LOGO, THE SUN OF MIRÓ}

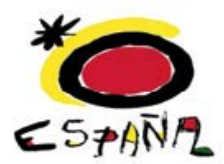

Source: Spanish Ministry of Industry, Commerce and Tourism (https://www.mincotur.gob.es/es-ES/GabinetePrensa/NotasPrensa/2010/Paginas/npConvenioCorteInglesTurespana.aspx).

Last date accessed: 23/06/2020.

Apart from adopting the Sun of Miró as the one and only country's logo in 1984, Spain also launched in the same year the first campaign intended to promote the country abroad after democracy was re-established. The slogan chosen for this occasion was "Spain, everything under the Sun”. Aside from focusing on the sun one more time, the campaign also tried to add cultural and artistic connotations to the image of country by including in its audiovisual materials some of the pictorial works by Goya and Velázquez together with images of ski resorts, Atlantic landscapes and some of the country's traditional gastronomy.

\section{Figure 4 \\ SPAIN, EVERYTHING UNDER THE SUN}
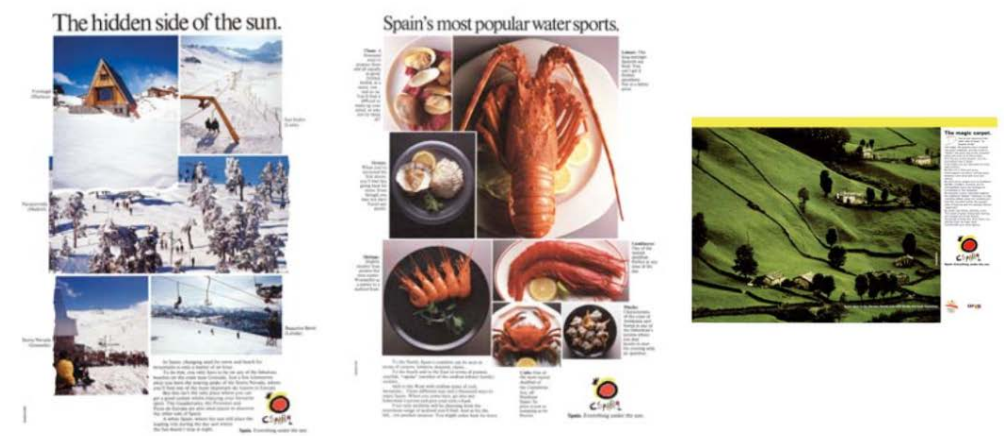

Source: Tourspain (https://www.tourspain.es/es-es/conózcanos/historicopublicidad).Last date accessed: $26 / 03 / 2020$. 


\subsection{Spain. Passion for life (1991-1995)}

The year 1992 supposed a record for Spain in terms of its visualisation worldwide since two major international events were held in the country. On the one side, Barcelona became the only Spanish city that has ever hosted the Olympic Games. On the other side, the World Expo took place in the city of Seville. Having in mind these two international events, a new communication campaign was launched by Tourspain one year earlier. The slogan chosen was "Spain. Passion for life". Crain claims that the intention of the campaign was to go beyond the overused image of a sunny country by highlighting the Spanish culture and arts:

"An earlier focus and the beach culture was replaced by images and written texts that touted Spain's unique cultural and artistic heritage. This strategy redirected attention towards the nation's sophisticated urban centres and historic landmarks during 1992, a year in which Madrid was chosen as the cultural capital city of Europe, Barcelona as the host of the summer Olympics, and Seville, as the site of World's Fair"' (1996: 29).

In line with Crain, Cooper points out that the campaign "faced with the loss of a strong Spanish image for its resort areas, embarked upon an exercise to reposition and rebrand the country. The history, culture, traditions and inland areas had been under promoted and weakly communicated" (Cooper, 2008:616).

The audiovisual materials conforming "Spain. Passion for life" included Spanish athletes, references to the national gastronomy and the alleged character of Spaniards through the use of positive nouns such as triumph, talent and warm, which recurrently appeared as focal points in the different formats that the campaign adopted.

\section{Figure 5 \\ SPAIN, PASSION FOR LIFE}
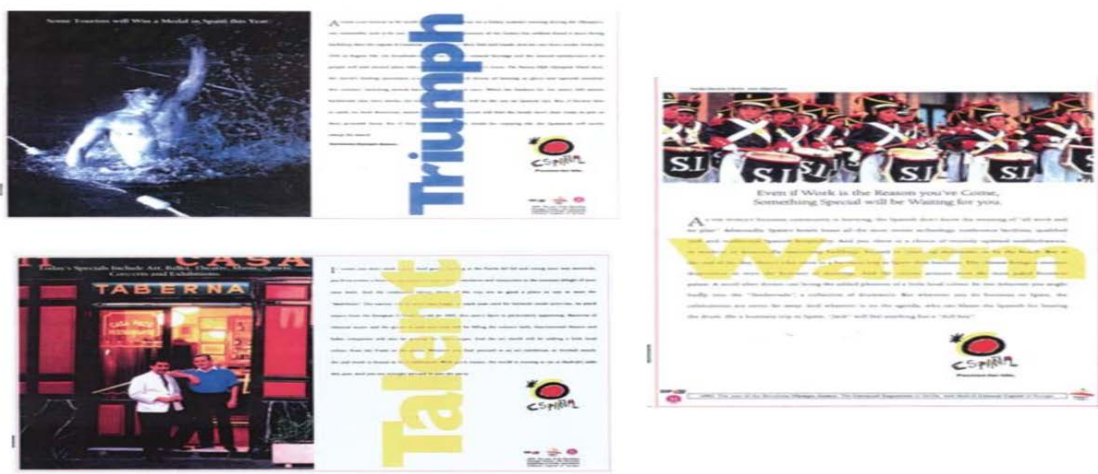

Source: Tourspain (https://www.tourspain.es/es-es/conózcanos/historicopublicidad).

Last date accessed: 26/03/2020. 


\subsection{Spain by... (1995-1998)}

In 1995 a new campaign with the slogan "Spain by..." was aired. According to what Tourspain claims in its website, the intention was to offer different visions on the country through the works of some internationally renowned photographers. Morgan, Pritchard et al. considered the campaign to be a complete failure since, according to their views, it did not manage to have any impact on the image of the country as it was intended (2002:74).

From an iconic point of view, "Spain by..." kept on using female models wearing traditional Spanish accessories such as peinetas or abanicos. Male models playing football on the beach and art museums were also included in the audiovisual materials of the campaign. It is worth mentioning that some of the models, both males and female were topless, a fact that could have contributed to add sexual connotations to the international image of the country and its people (s).

\section{Figure 6 SPAIN BY...}

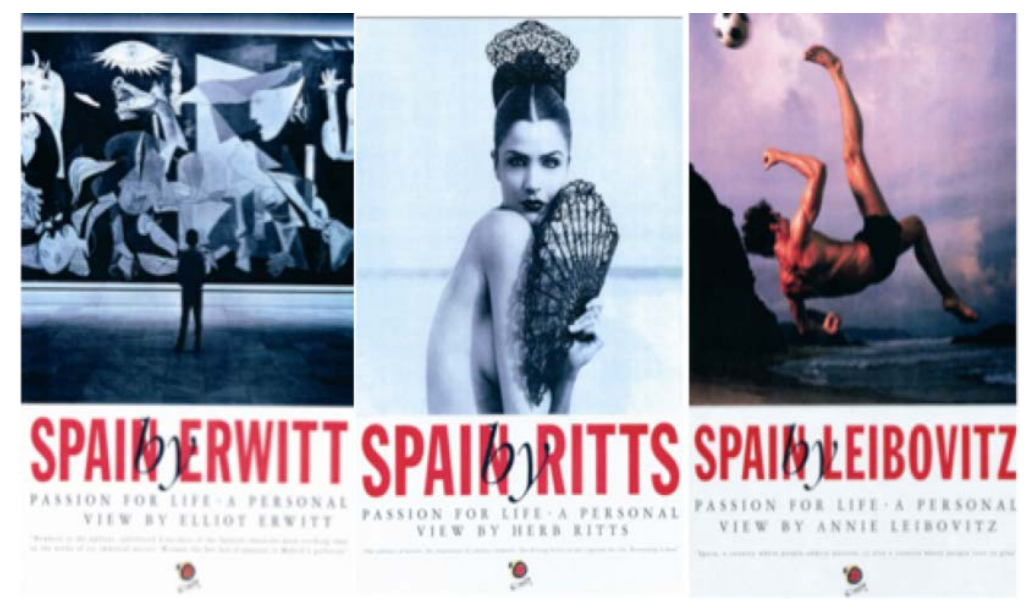

Source: Tourspain (https://www.tourspain.es/es-es/conózcanos/historicopublicidad).

Last date accessed: 26/03/2020.

\subsection{Bravo Spain (1998-2002)}

"Spain by..." was replaced by "Bravo Spain" in 1998. Morgan, Pritchard et al. point out that this new campaign "was tested in the key markets of the UK, Germany and France, where it was seen in a positive way: the word Bravo conjures up images of approval, allaying fears in Spain of any negative connotations of its association with bullfighting" (2002:72).

According to Tourspain, the word bravo can be easily pronounced in all languages and, at the same time, carried the messages that the campaign intended to communicate. Its main objectives were to gain the loyalty of regular visitors, promote inner parts of the 
country as cultural destinations and attract new visitors with a higher purchasing power ${ }^{26}$. Lennon, Smith et al. highlight that Bravo Spain was "the first attempt at moving away from Spain's dependence on sun and beach and developing a new brand image of the country-e.g. as a cultural and gastronomic paradise" (2006:219).

"Bravo Spain" also resulted in the first campaign launched by the Spanish government to promote the country as an international tourist destination whose imagery did not include any female or male models in any of its audiovisual materials, which were all based on geographical resources or emblematic buildings such as the Mosque of Cordoba or the Guggenheim museum in Bilbao.

\section{Figure 7 \\ BRAVO SPAIN}
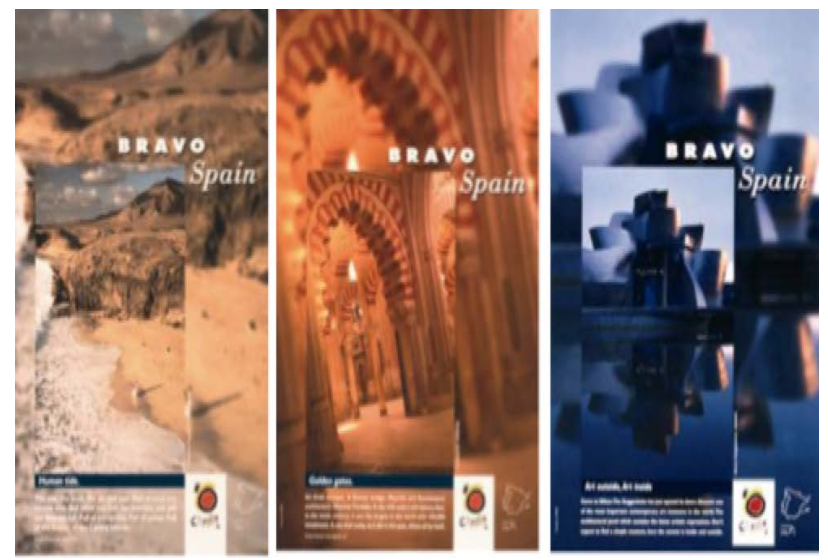

Source: Tourspain (https://www.tourspain.es/es-es/conózcanos/historicopublicidad).

Last date accessed: 26/03/2020.

\subsection{Spain marks (2002-2004)}

"Spain marks" has been considered one of the most original and innovative campaigns ever launched by Tourspain. Lennon, Smith at al. claim in this regard that it "highlights the different attractions and activities available to tourists in different parts of Spain - goes a few steps further, positioning the destination in terms of lifestyle as well as attractions" (2006:219).

The campaign presented images of both male and female models with "marks" on their bodies associated with Spain, including the naked back of a woman showing the tan line of a thong, a male model with the tan line of a diving mask on his face and feet with the tan line left by beach shoes.

26 Original quotation in Spanish: "En 1998 y bajo el slogan "Bravo Spain”, se crea una nueva campaña de comunicación con un slogan rotundo y memorable, de fácil e igual pronunciación en todos los idiomas. Transmite una imagen de España como un país moderno, con calidad y diversidad, y persigue fidelizar a sus visitantes en productos alternativos al sol y playa, captando un turismo de mayor capacidad de gasto". Available on: https://www.tourspain.es/es-es/conózcanos/historicopublicidad. Last date accessed: 01/04/2020. 


\section{Figures 8 SPAIN MARKS}
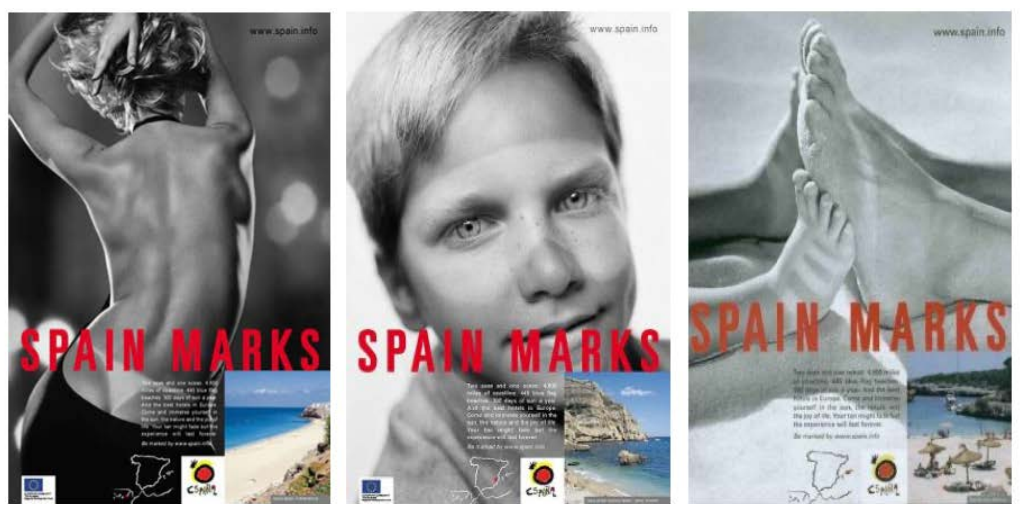

Source: Porres-Guerrero and Foranda-Robles (2019).

\subsection{Smile! You are in Spain (2004-2008)}

The campaign "Smile! You are in Spain" emphasized the symbolic value that some Spanish emblematic constructions such as the Alhambra of Granada, the Sagrada Familia and the Agbar Tower in Barcelona, the Guggenheim Museum of Bilbao or the Square of Chueca in Madrid have (Bazaga Sanz, 2015:13).

It is worth noting that the first direct reference to LGBT tourism made by a campaign supported with public funds in the history of the promotion of Spain abroad appeared on one of the posters included in "Smile! You are in Spain". This specific poster represented a couple of two men posing together in the Square of the Chueca neighbourhood in Madrid. Other images included in the audiovisual materials of the campaign depicted a female flamenco dancer, a surfer on the beach, congressmen in a sunny historical site and golf players.

\section{Figure 9}

\section{SMILE! YOU ARE IN SPAIN}
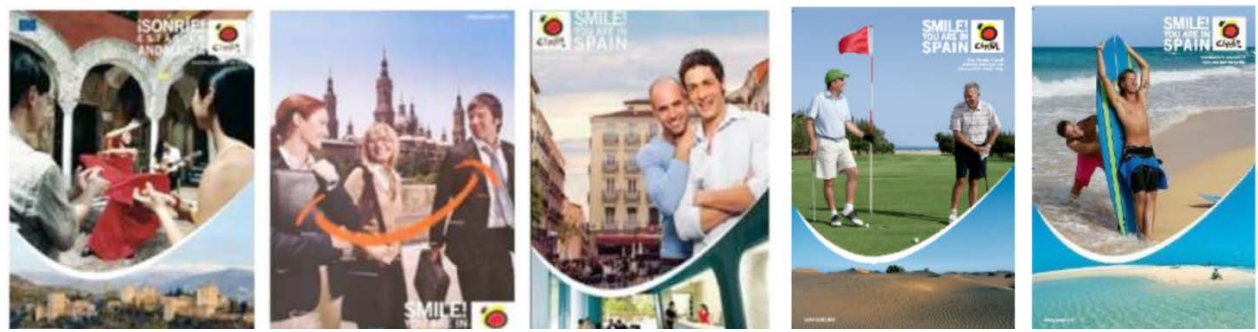

Source: Tourspain (https://www.tourspain.es/es-es/conózcanos/historicopublicidad). Last date accessed: 26/03/2020. 


\subsection{Spain, 25 years under the sun (2008-2011)}

On the $25^{\text {th }}$ anniversary of the adoption of Miró's sun as the official logo of Tourspain, another campaign - "Spain, 25 years beyond the Sun"-was launched in parallel to "Smile! You are in Spain". According to Tourspain, the creative narrative of "Spain, 25 years beyond the Sun" was based on traveling back in time with tourists who visited the country twenty-five years ago and are still enjoying its sunny beaches, gastronomy, culture, modern architecture and shopping nowadays ${ }^{27}$. Consequently, the audiovisual materials that gave form to the campaign included different collages combining old and present images of the country and its visitors. It is important to note that, to the best of our knowledge, even though the campaign used old tourist images of the country, any of them were related to flamenco, bullfighting, sun or beaches.

\section{Figure 9 \\ SPAIN, 25 YEARS BEYOND THE SUN}
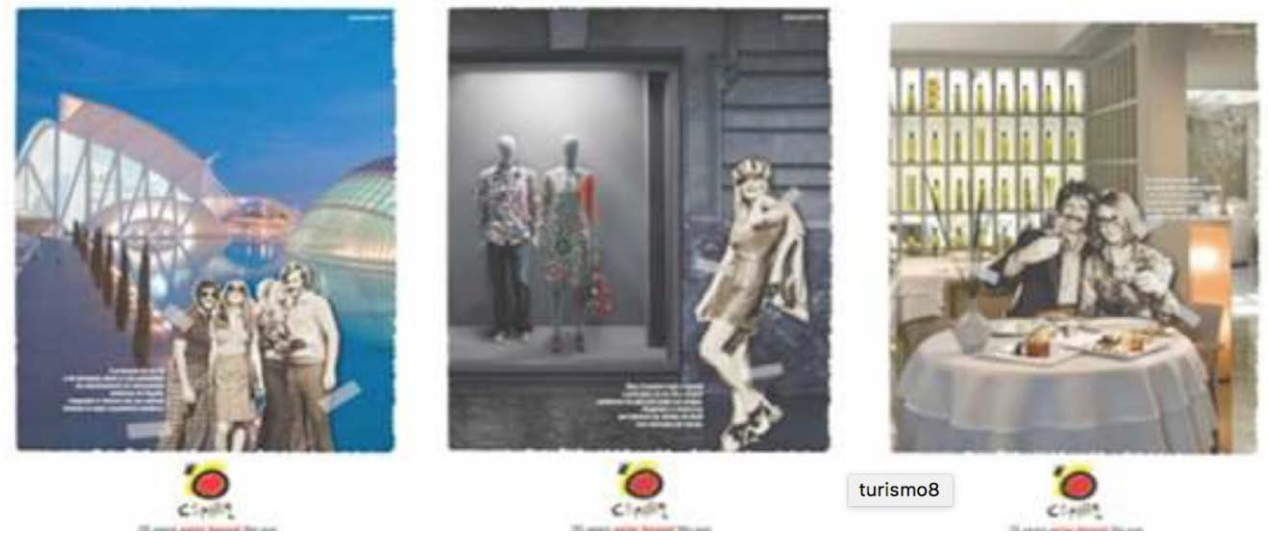

Source: Tourspain (https://www.tourspain.es/es-es/conózcanos/historicopublicidad).

Last date accessed: 26/03/2020.

\subsection{I need Spain (2010) and Spain addicts (2011)}

"I need Spain" was launched in 2010 with two objectives. On the one hand, it strived towards the reinforcement of the image of the country as a consolidated destination that is able to offer a wide range of quality tourist attractions. On the other hand, it attempted to access the emerging Asian markets with a well-defined and established brand. In order to achieve these two goals, prominent Spanish personalities such as Julio Médem (film

27 Original quotation in Spanish: "El argumento de la creatividad es un "viaje por el tiempo" en el que los turistas de hace 25 años disfrutan de la España de hoy y de sus principales atractivos: sol y playa, gastronomía, cultura, arquitectura contemporánea y compras".

Source: https://www.tourspain.es/en-us/Conozcanos/Pages/HistoricoPublicidad.aspx. Last date accessed: 01/04/2016. 
director), Gisela Pulido (athlete), Ferrán Adrià (chef) and both national teams of basketball and football participated in the campaign. It was launched in different formats and platforms, putting emphasis on social networks and, in general, on its presence on the Internet. A website for the campaign was specifically created (www.ineedspain.com, no longer in use) and a sub-campaign, "Spain addicts", was exclusively launched in parallel on social media $^{28}$. The audiovisual materials included in "Spain addicts" made use of the sun as a recurrent element to depict Spanish landscapes together with references to the sea, party, sports, shopping and gastronomy.

\section{Figure 10 \\ I NEED SPAIN}
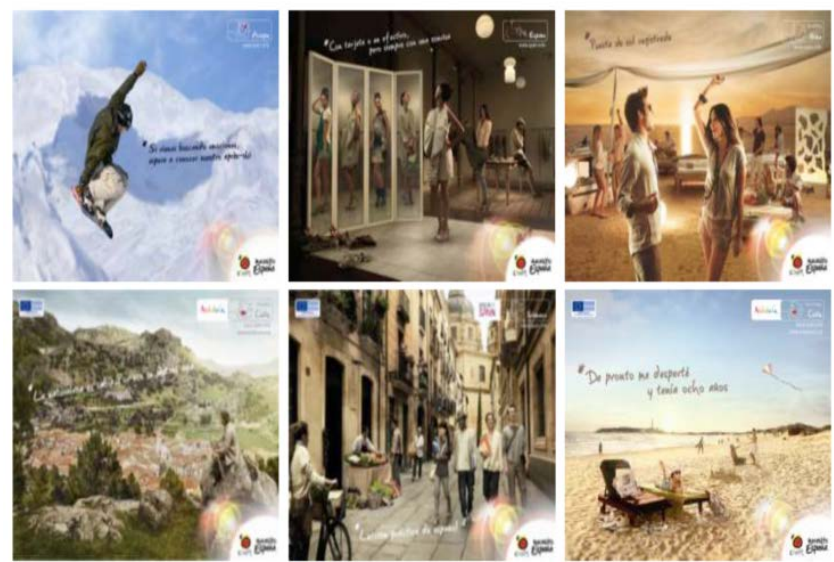

Source: Tourspain (https://www.tourspain.es/es-es/conózcanos/historicopublicidad).

Last date accessed: 26/03/2020.

\subsection{Spain is part of you (2016)}

"Spain is part of you" was launched in 2016. According to the video that presented the campaign ${ }^{29}$, its main objective was to attract tourists with a higher purchasing power who enjoy arts, cities and the gastronomy of the country. This video literally mentions that one of the purposes of the campaign is to leave bullfighting, sun and paella behind.

The audiovisual materials created for "Spain is part of you" included four videos, each of them dedicated to one specific segment among its target publics, that is, solo travellers, families, seniors and far markets. Apart from the videos, the campaign also made use of twenty different posters also in line with its target publics. Out of these posters, six were based on specific monuments and/or cities, four presented the sea in the foreground, two

28 Source: https://www.tourspain.es/en-us/Conozcanos/Pages/HistoricoPublicidad.aspx. Last date accessed: 01/04/2016.

29 Source: http://press.spainispartofyou.com. Last date accessed: 01/04/2020. 
showed culinary elements and two were filmed inside shopping boutiques ${ }^{30}$. It should be noted that the presence of male and female models in the campaign was exclusively limited to background images.

\section{Figure 11 \\ SPAIN IS PART OF YOU}

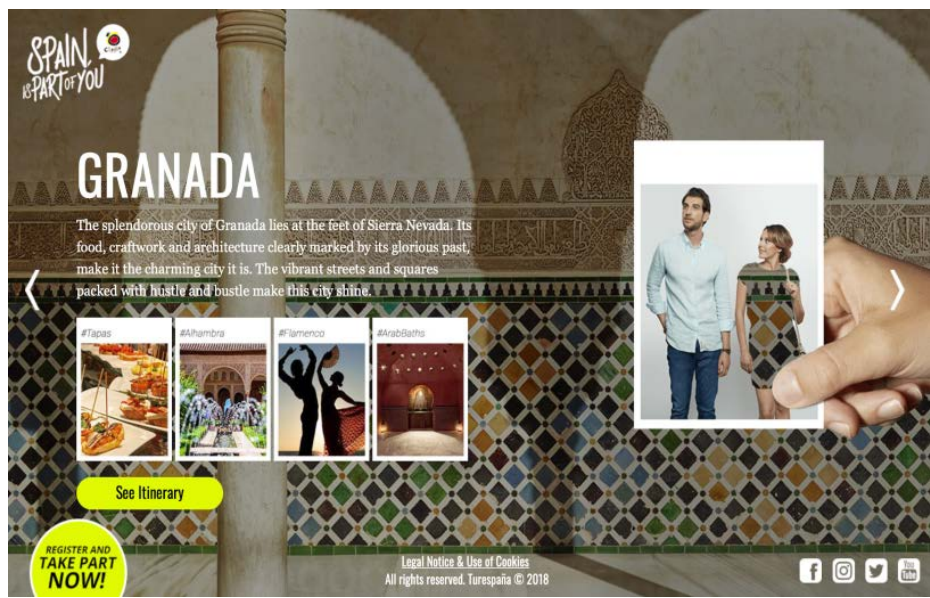

Source: http://spainispartofyou.spain.info/uk/\#trip. Last date accessed: 26/03/2020.

\subsection{Spain in ten seconds $(2018)$}

The most recent campaign launched to promote Spain as a tourist destination came to light in April 2018. According to Tourspain, this new campaign was:

"spearheaded by 12 prominent Spanish personalities from the fashion and art, culture, sports and entertainment sectors and drawing on their personal experiences showcasing Spain as a travel destination. Launched via Spain's official social media channels, each ambassador highlights what they love about Spain through a series of short videos, encouraging other social media users to do the same" 31 .

Some of the personalities that participated in the campaign are Luis Rojas Marcos (scientist), Carolina Marín (Olympic champion), Elsa Pataky (actress), Juan Mari Arzak (chef), Paz Vega (actress), Tamara Rojo (director of the English National Ballet), Javier Fernández (Olympic champion), Ágatha Ruiz de la Prada (fashion designer), Sergio García (golfer), Rafael Nadal (tennis player) and Fernando Alonso (Formula 1 world champion). Each of these celebrities introduced at least two videos of their favourite des-

30 All these audiovisual materials are available on its official website (http://spainispartofyou.spain.info). Last date accessed: 01/04/2020.

31 Source: http://socialnewsroom.spain.info/the-spanish-tourist-office-launches-new-campaign-spainin-10-seconds. Date accessed: 1 July 2018. 
tinations in Spain and explained the reasons why they fell in love with them. The creative narrative of the whole campaign is based on "a study saying that it's possible to fall in love just by staring at someone for a few seconds. Something very similar to what you feel each time you visit Spain"32.

With regards to the audiovisual materials that have been launched so far, they have mainly depicted natural and urban landscapes accompanied by the comments of one Spanish personality each. Some of the landscapes selected have included sun and/or sea sceneries, as well as cities, natural reserves and landscapes.

\section{CONCLUSIONS}

Having taken into consideration the different historical views on Spain gathered together along this paper, it can be claimed that the imagery around it appears to have conceived the country as a special Western European enclave where travellers can experience old-fashioned lifestyles already extinct in other Western European nations. This romantic conceptualisation seems to have laid the foundations for the present Spanish national stereotypes and clichés (e.g. Hoffman, 1961; García Felguera, 1981; Aymes, 1983; González Troyano, 1987; Álvarez Junco, 1994; Calvo Serraller, 1995; Núñez Florencio, 2001 and Ortas Durand, 2005).

Focussing on the institutional promotion of the country as an international tourist destination, the myths embedded in the construction of its national image appear to be linked to the narratives of exoticism and traditionalism. The first slogan "Spain is different", which was uninterruptedly used for more than fifty years, clearly reflected the country's self-views as peculiar and exceptional. The images of sunny landscapes, beaches, bullfighting arenas and Spaniards wearing traditional dresses that were portrayed in the first campaigns seem to have served to visually enhance these exotic and traditionalist views on the country and its people (s) abroad.

We believe that Spain may be still perceived as different from other Western European nations nowadays. However, this perception could be evoking some kind of fascination that, together with a well-developed touristic offer, makes the number of international visitors to keep on growing year by year ${ }^{33}$. From an academic perspective, an important number of authors have highlighted the existence of exotic connotations around the image of Spain and its people (s) in their works (e.g. Juderías, 1914; Ucelay, 1990; Noya, 2002, 2013; Feo et al., 2004; Lucena, 2006; Balfour and Quiroga, 2007; Mariné-Roig, 2011 and Núñez Florencio, 2015).

As explained along the analysis carried out on its different campaigns, the Spanish central government has tried to vary the imagery used to promote the country abroad throughout time in order to leave aside stereotypes and clichés. However, the audiovisual materials included in them have shown a recurrent use of elements that coincide with some of the classical national stereotypes described by Noya $(2005,2013)$, Belford and Quiroga (2007) or Núñez Florencio (2015). These elements are also clearly connected with soft

32 Source: https://www.spainin10sec.com. Last date accessed: 01/04/2020.

33 In 2018 the country received 82.8 million visitors, a 1.1\% rise from 2017 according to the figures released by the National Statistics Institute (INE). 
power factors such as sun, sea, arts, gastronomy and beauty, which appear to have reinforced the pre-existing exotic views on Spain and its people (s) rather than getting away from them. To the light of these reinforcement, we believe that the promotion of the country abroad has not successfully managed to leave aside the narratives linking the identity and idiosyncrasy of the country with exoticism. In a more precise way, specific references to sun and beaches have been found in all the campaigns launched so far. Furthermore, the sun has been one of the central elements in the audiovisual materials of half of the campaigns ("Spain is different", "Spain. Everything under the Sun", "Bravo Spain", "Spain marks", "Spain, 25 years beyond the Sun", "I need Spain" and "Spain is part of you"). If we focus on the depiction of Spaniards, a drastic change from the first campaigns to the most recent ones deserves to be noted. In that sense, the images representing Spanish men as villagers or bullfighters and Spanish women wearing flamenco dresses, mantillas or peinetas have been gradually substituted by more neutral representations, including an important number of personalities from the fields of arts and sports in the last campaigns ("Spain by", "I need Spain" and "Spain in 10 seconds"). Even so, it is important to note that some sexual connotations around the representations of Spaniards have been found in "Spain by..." (1995) and "Spain marks" (2002). More specifically, "Spain by..." included the image of a naked woman wearing only a peineta on top of a hair bun while in "Spain marks" the back of a semi-naked woman showing the tan lines left on her skin by a thong was used. Moreover, we believe that some sexual connotations may be perceived from the first poster created in 1914, whose creative design revolved around a woman wearing a tight black dress with mantilla, peineta and red lipstick on. The fact that these three images triggering the construction of sexual connotation around Spaniards focused exclusively on women has also caught our attention.

To the light of the presence of public personalities in the last campaigns, it seems clear that the Spanish public institutions in charge of promoting the country abroad have opted for making use of the so-called celebrity diplomacy (Cooper and Frechette, 2008). Proof of this is the appearance of world-known Spanish celebrities including Rafael Nadal (tennis player), Fernando Alonso (formula 1 driver), Javier Hernández (football player) or Elsa Pataky (actress) in the last marketing campaigns of Tourspain. It should be pointed out in this line that any of the personalities who have collaborated so far in the campaigns belong to any field that could be considered hard power (e.g. economy, science, politics or technology).

We would also like to mention that parallelisms between the Yellow Legend and soft power factors on the one hand and between the Black Legend and hard power factors on the other have been noticed along the analysis carried out on the imagery used in the campaigns. Our view is that Spain seems to be currently undergoing - again - a sort of new Black Legend period due to its inability to dispose of old stereotypes and lay emphasis on its hard power instead. In addition, the impact of the well-known country's soft power is so significant that it could be emphasizing and reinforcing pre-existing romantic and exotic connotations as during the Yellow Legend period.

Considering all the above-mentioned points, it seems reasonable to assume that Spain has made an important effort over the years in order to promote a touristic image closely linked to sun, beaches, culture and arts, which has indirectly - and perhaps unin- 
tentionally - helped to expand some of its old national clichés and stereotypes. We believe that deviating attention from these deeply embedded images about the country and its people (s) is a very difficult task to achieve, at least in the short term. This is due to the fact that the Spanish authorities has little control over the narratives that, about the country and its people (s), generate and circulate within the current global discourses of press, news and creative industries such as cinema, music, advertising or literature. However, we believe that adding more value to the scientific, industrial and technological achievements of the country and its people (s) in future campaigns could be potentially beneficial for their international image and reputation. Apart from Tourspain, other Spanish public institutions as the Royal Institute Elcano [Real Instituto Elcano] or the Spanish national Institute of Cinematography and Visual Arts [Instituto de la Cinematografía y de las Artes Audiovisuales] could also potentially contribute on this direction. By way of example, the Spanish national Institute of Cinematography and Visual Arts has invested between 2005 and 2019 more than thirteen million euros ${ }^{34}$ in international films in English co-produced by Spain with the UK and the USA which included Spanish characters and locations in contrast with other national identities.

\section{BIBLIOGRAPHY}

ÁLVAREZ JUNCO, J. (1994): «El peso del estereotipo». Claves de Razón Práctica, n48, pp. 2-10.

ANDRÉS-GALLEJO, J. (1981): Historia general de España y América. Tomo XVI-2: Revolucióny Restauración. Rialp, Madrid.

AYMES, J.R. (1983): L'Espagne romantique (Témoignages de voyageurs français). Métailié, Paris.

BALFOUR, S. (1997): The end of the Spanish Empire, 1828-1923. Clarendon Press, Oxford.

BALFOUR, S. and QUIROGA, A. (2007): The Reinvention of Spain: Nation and Identity since Democracy. Oxford University Press, Oxford.

BAYÓN, F. (1999): 50 años del turismo español. Un análisis histórico y estructural. Centro de Estudios Ramón Areces, Madrid.

BAZAGA SANZ, R. (2015): «Publicidad y Arquitectura. Una relación simbiótica.»I +Diseño: revista internacional de investigación, innovación y desarrollo en diseño, vol. 10, (10), pp. 99-116.

BRAUN, R.A. and MCGRATTAN, E.R. (1993): «The Macroeconomics of War and Peace». NBER Macroeconomics Annual 1993, vol. 8, pp. 197-258,

BELLMAN, J. (1998): «The exotic in Western music». Second Series, Vol. 56 (1), (September 1999). Music Library Association, pp. 101-103.

CALVO SERRALLER, F. (1995): La imagen romántica de España. Arte y arquitectura del siglo XIX. Alianza, Madrid.

34 This figure has been calculated with the information on public funds provided by the Spanish Ministry of Education, Culture and Sports in its database of classified movies available at http://www.mecd.gob.es/cultura/ areas/cine/mc/catalogodecine/inicio.html. Last date accessed: 07/10/2019. 
CANAL, J. (2005): «El nacionalismo catalán: mitos y lugares de la memoria». Revista Histórica y Política, $\mathrm{n}^{\circ}$ 14, pp. 45-84.

CLEMENTE, J. C. (1999): El carlismo en su prensa (1931-1972). Fundamentos, Madrid.

CRAIN, M. (1996): "Contested Territories: The Politics of Touristic Development at the Shrine of El Rocío in Southwestern Andalusia”. In Boissevain, J. (Ed.) Coping with Tourist: European Reactions to Mass Tourism, pp. 27-55. Berghahn Books: Oxford. COOPER, A.F. and FRECHETTE, L. (2015): Celebrity diplomacy. Routledge, London.

ESCALONA ORCAO, A., SÁEZ PÉREZ, L. and SÁNCHEZ-VALVERDE GARCÍA, B. (2017): «Patterns and drivers of cultural economy in Spain's extra-metropolitan small towns». Investigaciones Regionales, $\mathrm{n}^{\mathrm{0}} 38$, pp. 27-45.

ENGSTRAND, I. (1985): «The Enlightenment in Spain: Influences upon New World Policies». In Vinson III, B. (Ed.): The Americas, Volume 41, Issue 04, April 1985. Cambridge University Press: Cambridge, pp 436-444.

FEO, J. (Ed.), MORALEJO, A and TORRES, C. (2004): Liber Sancti Jacobi «Codex Calixtinus». Xunta de Galicia: Santiago de Compostela.

FERNÁNDEZ POYATOS, M.D. and VALERO ESCANDELL, J.R. (2015): «Carteles, Publicidad y Territorio: La Creación de la Identidad Turística en España (1929-1936) ». Cuadernos de Turismo, no 35, pp. 157-184.

FERGUSON, N. (2007): The War of the World: Twentieth Century Conflict and the Descent of the West. Penguin Books: New York.

GARCÍA CÁRCEL, R. (1998): La leyenda negra: historia y opinión. Alianza Editorial: Madrid.

GARCÍA CÁRCEL, R. (2013): «Castilla y Cataluña, amor y odio: Cultivar la diferencia». La Aventura de la Historia, $\mathrm{n}^{\circ} 182$, pp.16-22.

GARCÍA FELGUERA, M. (1981): Imagen romántica de España. Palacio de Velázquez, Madrid.

GARRIDO LORA, M. (2005): «Comportamiento estratégico de la promoción turística española».Comunicación, $\mathrm{n}^{\circ}$ 3, pp. 125-140.

GONZÁLEZ MORALES, J.C. (2005): «La Comisión nacional de Turismo y las primera iniciativas para el fomento del turismo: La industria de los forasteros (1905-1911)», Estudios Turísticos, n ${ }^{\circ}$ 163-164, pp.17-30.

GONZÁLEZ TROYANO, A. (1987): La imagen de Andalucía en los viajeros románticos y homenaje a Gerald Brenan. Diputación Provincial de Málaga, Málaga.

HAMILTON, E. (1938): «The decline of Spain». Economic History Review, no 8. Wiley Blackwell on behalf of Economic History Society, pp.168- 179.

HOFFMANN, L.F. (1961): Romantique Espagne - L'image de l'Espagne en France entre 1800 et 1850 . University of Princeton: New Jersey.

HOYOS SÁINZ, L. and DE HOYOS SANCHO, N. (1953): «Zonas de ornamentación en los trajes populares de España», Revista de Dialectología y Tradiciones Populares, $\mathrm{n}^{\circ}$ 29, pp. 126-139.

ILIFFE, R. (2003): «Science and voyages of discovery». In Roy, P. (Ed.): The Cambridge History of Science, Volume 4 Eighteenth-Century Science. Cambridge University Press: Cambridge, pp. 618- 646. 
JIMÉNEZ, S. and PRATS, L. (2006): «El turismo en Cataluña: evolución histórica y retos de futuro». Pasos: Revista de Turismo y Patrimonio Cultural, vol. 4 (2), pp. 153-174.

JUDERÍAS, J. (2014): La leyenda negra (re-edición del original publicado en 1914). Ediciones Atlas, Madrid.

LENNON, J., SMITH, H. and COCKERELL, N. (2006): Benchmarking National Tourism Organisations and Agencies. Understanding Best Practice. London: Elsevier.

LIPPMAN, W. (1922): Public Opinion. Harcourt, Brace.

LUCENA GIRALDO, M. (2006): «Los estereotipos de la imagen de España». Proyecto M.E.C. BHA20003-01267, España desde fuera. Norba. Revista de Historia, ${ }^{\circ}{ }^{\circ}$, , pp. 219-229.

MACCLANCY, J. (2010): The decline of Carlism. University of Nevada Press, Reno and Las Vegas.

MORGAN, N. and PRITCHARD, A. (2013): Advertising in Tourism and Leisure. Butterworth Heinemann, Oxford.

NOYA, J. (2002): La imagen de España en el Exterior. Estado de la Cuestión. Real Instituto Elcano de Estudios Internacionales y Estratégicos, Madrid.

NOYA, J. (2013): La imagen de España en el mundo (Volumen II). Tecnos, Madrid.

NÚÑEZ FLORENCIO, R. (2001): Sol y sangre. La imagen de España en el mundo. Espasa, Madrid.

NUÑEZ FLORENCIO, R. (2015): «La construcción de la realidad española: símbolos, mitos y tipos». La Albolafia: Revista de Humanidades y Cultura, no 5, pp. 171-190.

ORTAS DURAND, E. (2005): «Apéndice bibliográfico sobre viajes y viajeros por España en los siglos XVIII y XIX». In Leonardo Romero Tobar y Patricia Almárcegui Elduayen (Coords.) Los libros de viaje: realidad vivida y género literario, Madrid, AkalUniversidad Internacional de Andalucía, 2005, pp. 92- 103.

PORRES GUERRERO, M. and FORONDA ROBLES, C. (2019): «Where is the humour in tourism promotion? An investigation of the "Spain marks" campaign». European Journal of Humour Research, vol.7 (3), pp. 46-62.

ROBERTSON, I. (1988): Los curiosos impertinentes. Viajeros ingleses por España desde la accesión de Carlos III hasta 1855. Serbal-CSIC, Barcelona.

ROCKMORE, R. (2015): «Dancing with the ideal masculinity». In Goldberg, M. Bannahaus, N. and Heffer Hayes, M. (Eds.) Flamenco on the Global Stage: Historical, Critical and Theoretical Perspectives. McFarland and Company Publications. Jefferson, North Carolina, pp. 234-243.

SÁNCHEZ SÁNCHEZ, E. (2001): «El auge del turismo europeo en la España de los años 60». Arbor CLXX, 669, pp. 201-224.

SANTANA PEREIRA, J., RAIMUNDO, F. \& COSTA PINTO, A. (2016): «An ever-shadowed past? Citizen's Attitudes towards the Dictatorship in the Twenty-First Century». South European Society and Politics Journal, vol. 21 (2). pp. 197-210.

STORM, E. (2013): «Una España más española. La influencia del turismo en la imagen nacional». In Moreno Luzón J. and Núñez Seixas, X.M. (Ed.) Ser españoles. Imaginarios nacionalistas en el siglo XX. RBA, Barcelona, pp. 530-560.

STREISSGUTH, T. (2007): The Roaring Twenties. Facts on file, Infobase Publishing: New York. 
THOMPSON, G. (2010): The Birth of Modern Politics in Spain: Democracy, Association and Revolution, 1854-1875. Palgrave Macmillan, London.

UCELAY, E. (1990): «Ideas preconcebidas y estereotipos en las interpretaciones de la Guerra Civil española: el dorso de la solidaridad». Revista Historia Social, nº 6, pp. 23-43.

WHARTON, B. (2015): More than just La Movida Madrileña; popular music and cultural change in 1980's Spain. Scripta Mediterranea, Vol. XXIX, pp. 52-65

WINSTON, C.M. (1985): Workers and the Right in Spain, 1900-1936. Prince town University Press, New Jersey.

WRIGHT, A. (1997): The Spanish Economy, 1959-1976. The Macmillan Press, London.

ZOEPF, K. (2006): «Barcelona, Spain: Hair Ornaments». In The New York Times, Late Edition (East Coast); New York, N.Y. 14 May 2006, pp. 5-6. 